Article

\title{
How Intellectual Property Management Capability and Network Strategy Affect Open Technological Innovation in the Korean New Information Communications Technology Industry
}

\author{
So Young Kim ${ }^{1}$ and Eungdo Kim ${ }^{2, *}$ \\ 1 Future Technology Analysis Center, Korea Institute of Science and Technology Information, Seoul 02456, \\ Korea; sykim8171@kisti.re.kr \\ 2 Graduate School of Health Science Business Convergence, College of Medicine, \\ Chungbuk National University, Cheongju 28644, Korea \\ * Correspondence: edkim@chungbuk.ac.kr; Tel.: +82-010-9059-1931
}

Received: 14 June 2018; Accepted: 17 July 2018; Published: 24 July 2018

\begin{abstract}
This paper analyses factors in open innovation activity in the Korean new information and communications technology (ICT) industry, with a focus on cooperation network strategy and intellectual property (IP) management capability, by applying multiple regression models with data collected from 300 companies within the industry. The results of this analysis suggested that the intensity and variation of a company's technological cooperation with a new ICT company has a statistically meaningful impact on its innovation. In particular, the impact depended on the type of cooperation network. Though IP management capability was also shown to have an important influence on a new ICT company's innovation, the impact of specific actions for IP management varied by the specific type of innovation results. This study suggests that new ICT companies need to construct technological innovation networks using multiple external sources and enhance their IP management capability in order to increase their technological innovation performance. The factors influencing technological innovation are elements of open innovation, indicating the open technological innovativeness of the new ICT Industry.
\end{abstract}

Keywords: open innovation; resource based view; network strategy; intellectual property management; new ICT industry

\section{Introduction}

The open innovation paradigm offers a company the chance to profit extensively through innovation activities and the intellectual property (IP) management resulting from them. The paradigm stresses the importance of utilizing a large range of sources for innovation and innovative activities [1-3].

Previous studies have shown that network strategy and IP management strategy become more critical issues for the new ICT industry in the perspective of open innovation [4-7]. As characteristics of the new ICT industry such as easy diffusion of innovation outcomes, the necessity of external technology absorption and the strong influence of user innovation require reinforcing company's network strategy and varying detailed actions according to the place of opponent players in the ecosystem [8,9]. Researchers have also suggested that companies need to give more careful consideration to IP management in order to appropriate their innovation outcomes in the new ICT industry, which is characterized by rapid technology transition, frequent market entry and exit of players and interdependence among players in the ecosystem $[10,11]$. For many young and small 
companies in the new ICT industry, IP management strategy is particularly critical for the sake of protecting their idea, process and products. With an active open innovation trend in the ICT industry including collaborative R\&D, technology transfer and acquiring organizations, the 'appropriability' of technological achievements can be a strong incentive to innovation [10-12]. Also, the 'efficiency' of open innovation to be one of key factors that requires IP management [13]. In terms of inbound open innovation, IP management is important due to efficient processes for introducing external knowledge. In terms of outbound open innovation, IP management is necessary to monetize intellectual properties and to launch spin-off business.

The ICT industry has come to feature a horizontal relationship among industries through combining innovation and maximizing innovation values through external collaboration has become even more important $[14,15]$. The horizontal interaction between actors such as platform providers or content providers in the new ICT industry has been more likely to introduce an innovation in this sector $[16,17]$. As users change from being passive to active innovators, collaborating with user's role becomes increasingly important to innovation $[11,18]$. Moreover, managing innovation outcomes has become an important task in strengthening competitiveness and maximizing value.

Beside ICT industry, since many companies have embraced the enabling role of information technology [19], digital transformation has taken place across many industries [20,21]. In particular, manufacturing companies are increasingly acquiring and adopting Internet-of-Things (IoT) technologies from various sources of knowledge [22]. Digital transformation trend has extended the characteristics of the ICT industry such as easy diffusion of innovation outcomes, the necessity of external technology absorption to other industries [23].

Despite the many theoretical discussions of this topic, few studies have provided solid evidence that the new ICT industry's innovativeness has been produced through open innovation. Of course, exploring the various paths of technology adoption as an inbound open innovation practice has now become a traditional topic [24]. The paths have included R\&D collaborations [25,26], market of technologies and ideas [27], merger and acquisition of organizations [28]. This study aims to contribute to the existing literature by focusing on the specific cooperative strategy of the company, from whom to acquire knowledge and ideas. Although the research methodology that collects data through surveys based on companies is difficult to distinguish between inbound and outbound innovation [29], we focused more on inbound open innovation. Because it has become important to acquire and internalize the technologies and ideas associated with ICT technologies for the companies experiencing digital transformation and the companies in the new ICT industry.

This study focuses on the impact of a company's specific cooperation strategies and specific IP management strategies on its innovation performance in the open innovation environment and presents results and implications of the empirical case study for the Korean new ICT industry.

This paper examines open innovation activity in Korea's new ICT industry by applying multiple regression models with data collected from 300 companies. We seek, first, to confirm the open innovativeness of the new ICT industry by observing the effects of open innovation strategies on the industry's technological innovation performance. Second, we attempt to suggest policies that will strengthen the technological innovation capability of Korea's new ICT industry by analyzing the factors that affect the innovation performance.

This rest of this paper proceeds as follows. The second chapter reviews the literature about the characteristics of new ICT industry and intellectual property management in open innovation perspective. The third chapter describes the proposed research framework and hypotheses. The fourth chapter presents data, empirical model and results. The final chapter draws the discussion and policy implications. 


\section{Literature Review}

\subsection{Characteristics of the New ICT Industry from the Open Innovation Perspective}

The popularization of smart devices such as the smart phone, smart TV and smart tablet helps promote innovation within the industry, which in turn generates new values. The Internet acts as a catalyst for spontaneous behavioral changes both in users and in the unified environment, which diversifies content platforms and operating systems and facilitates the use of new ICT technology. This movement towards new ICT industry has accelerated since the appearance of smart devices.

We define the new ICT industry as the industry in which the upper layer players such as platform, contents and application providers have greater influence on the holistic industry ecosystem than the traditional players such as traditional telecommunication network and hardware companies have stronger gravitational forces [16]. The ecosystem of the new ICT industry consists of content, network, hardware and software sub-industries proposed in the ecosystem model [17] and the layer model [8].

The new ICT industry emerged due to a number of changes in the traditional ICT industry. Two major phenomena affect innovation in the new ICT industry: (1) an increase in user innovation and (2) an increase in open innovativeness [9,11]. First, as the information society continues to mature, the manufacturers and developers of hardware and software must work hard to keep abreast of these changes and the consumer's role continues to evolve from that of passive user to innovator [30]. Therefore, the user can be considered as a crucial participant in the innovation system [18]. The user involvement has become increasingly necessary for the innovation process with the emerging service such as the IoT as a result of recent technological advance [12,31].

In addition, as society enters into the digital age, convergence among industries have taken place due to the collapse of boundaries, generating new values created by companies within industries and companies produced by mergers among industries [17,32]. The innovative platform in new ICT ecosystem such as smart city [33] requires for collaboration among all actors in the industry ecosystem including ICT companies, governments, researchers and users. Thus, open innovativeness via internal and external network within the industry has significantly occurred $[2,5,6,34,35]$. As the Internet has become the 'Cyber-physical Infrastructure' [31] linking general physical objects as well as people, the companies of ICT sector, especially platform, content and applications layer, try to expand their business to various sectors such as manufacturing, healthcare, retail, energy and so on [36].

Simultaneously, ICT companies' cooperative innovation must be managed in a way that controls the interests of the stakeholders participating in their open innovation network [37]. Intellectual property management can help maintain innovation's drive in the open communication environments of ICT companies.

It is urgent that innovation be rapidly pursued in fields where no professional experience exists and where the technological environment changes rapidly, such as the ICT industry. To this end, companies can introduce innovation processes, begin to access external knowledge resources and manage their knowledge capacity in order to increase the number of innovation [5,35,38-40]. Those companies obtain innovation capability by acquiring external knowledge and technology by purchasing intellectual properties or the merger and acquisition of a company that has emerging and disruptive technologies [41].

\subsection{Intellectual Property Management and Open Innovation}

Intellectual property management has been investigated as a key factor affecting company's open technological innovation. Previous studies that reviewed the relationship between IP strategies and innovation practices and its contradictory attributes, found out that IP protection may have negative effects on open innovation because it ensures the appropriability of a company's R\&D achievement [42] while increased patent appropriability raises company's transaction costs [43]. Meanwhile, it is suggested that a direct (though not necessarily causal) correlation exists between appropriability and open innovation [12]. They have shown that open innovation was more vigorous in areas with 
high appropriability than in areas with low appropriability. Level of appropriability varies with the characteristics of industry's ecosystem [11]. A company cannot exclude competitors from an external source of core knowledge in a certain industry ecosystem. For example, in new ICT industry where network structure of a company affects its innovation performance, it is more important how to capture the value created by innovation in the ecosystem [10].

In a series of studies investigating the causes of the correlation between appropriability and open innovation, it is shown empirically that innovative companies participating in cooperation networks tend to manage their open innovation processes through 'formal contracts,' suggesting that innovative companies seek to enjoy the benefits of openness while also protecting their innovative capabilities [44]. Therefore, managing IP allows companies pursuing open innovation to reap the benefits of their innovation practices [35]. Particularly, companies in the new ICT industry can resolve the conflicts of interest by determining the potential share of each actor in advance by the formal contracts [45]. Open innovation requires many stakeholders to collaborate in cooperative activities such as co-invention, co-production and co-ownership. Open innovation must be managed formally to maintain its drive in the widely open and dynamic environments in which it operates $[37,46,47]$. Companies must thus coordinate and govern the conflicting interests of open innovation participants and create management policies for important intellectual properties.

Researchers have conducted empirical investigations on the impact of IP management strategies and capabilities such as reward systems and IP specialist teams on innovation, from patent records to financial performance [48-50]. The study has analyzed the relationship between the IP management strategies and innovation performance of Korean manufacturers [51]. They have also empirically shown that innovation output and financial performance depend on the IP management strategy of the company.

\subsection{Implications from Literature}

In the perspective of open innovation, network strategy and IP management become more critical issues for the new ICT industry. As characteristics of the new ICT industry such as easy diffusion of innovation outcomes, the necessity of external technology absorption and the strong influence of user innovation require reinforcing company's network strategy and varying detailed actions according to the place of opponent players in the ecosystem.

Companies need to give more careful consideration to IP management in order to appropriate their innovation outcome in the new ICT industry which is characterized by rapid technology transition, frequent market entry and exit of players and interdependence among players in the ecosystem. For many young and small companies in the new ICT industry, IP management strategy is particularly critical for the sake of protecting their idea, process and products.

Therefore, this study focuses on the impact of a company's specific cooperation strategies and specific IP management on its innovation performance in the open innovation environment and presents results and implications of the empirical case study for the Korean new ICT industry.

\section{Research Framework and Hypothesis}

The Resource Based View (RBV) explains how the organization achieves competitive advantage through innovation [52,53]. According to RBV, Each organization has a unique bundle of tangible and intangible resources and capabilities. [54,55]. Resources, the basic unit of RBV analysis can be defined as assets that are semi-permanently tied to the organization such as financial, physical, technological, human assets for developing and delivering product and services [54]. Whereas capabilities refer to the organization's ability to deploy and coordinate various resources to create innovation using organizational processes [53]. In RBV, the combination and utilization strategies of internal resources and external resources from other external organizations are essential to innovation [54,55].

Previous studies classify the factors of company innovation into tangible resources, intangible resources and strategies [54,56]. Following the classification, we have divided the decisive 
technological innovation factors for new ICT companies into company's strategy (network strategy), company's tangible (size, age, R\&D ratio) and intangible (IP management) resources and market structure (see Figure 1). Various types of network with companies, governments, universities and users comprise the company strategy factor; the existence of an IP management team, specialized IP management staff, internal training programs and compensation schemes comprise the company intangible factor; and size, age, R\&D expense ratio as the company's tangible factor, the companies' HHI as market structure. We also included Industry dummy (Hardware, Network, Software, Content) to compare the difference among them.

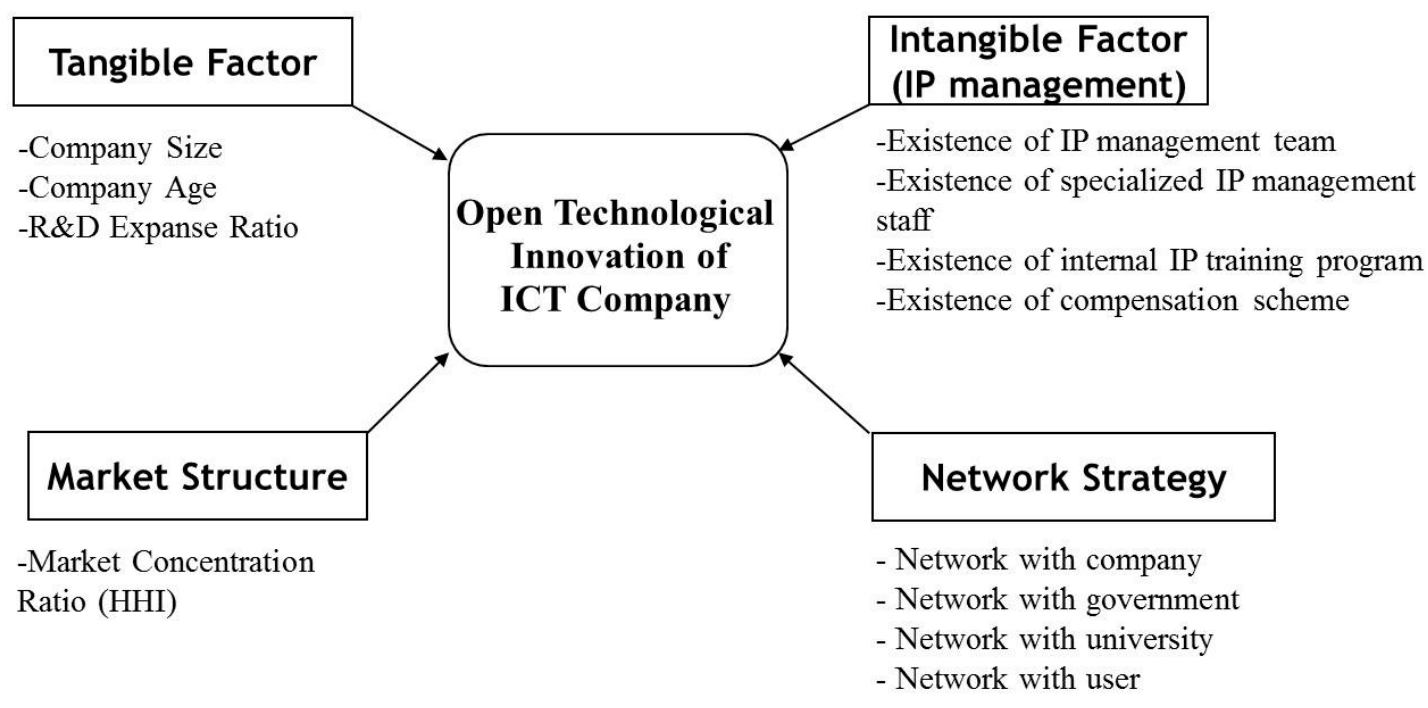

Figure 1. Factors affecting open technological innovation of Information Communication Technology (ICT) companies.

\subsection{Network Strategy}

The role of the external network in a company's innovation process is very important. Smaller companies, with fewer resources, technologies and R\&D capabilities than larger ones, are more likely to focus on external networks for technological innovation, as has been confirmed by many studies [11,57].

Patent outcomes relied on the regions' R\&D and university research levels and that small to medium-sized companies gained greater effects from external research than did large companies [58]. It is also confirmed that this effect can be observed in the US [58]. Network intensity has a proportional relationship with a company's technological innovation activities [59].

It is shown that the more a company searches for external knowledge, the greater the effect the company may gain from technological innovation [12]. The study has proposed that the size of the technical cooperation and interaction between affiliated companies positively influences the technological innovation and satisfaction rates of technical cooperation [60]. It is reported that these two kinds of co-operation separately influence product innovation by classifying co-operation into exploitive co-operation and explorative co-operation types [61].

To observe the network effects that external networks have on open technological innovation, this study first considers several different types of networks: networks between companies, networks with the government, networks with universities and networks with users. Here, 'networks' means activities that a company has experienced while acquiring technologies, ideas, or even human resources and their capabilities from the outside such as universities, institutes and other companies by contracted $R \& D$, collaboration, or informal interactions. We intend to propose the following hypotheses in order to demonstrate the relationship between network intensity and open technological innovation: 
Hypothesis 1. The more external networks a company has, the better its technological innovation performance will be.

Hypothesis 1a. The more networks with other companies a company has, the better its technological innovation performance will be.

Hypothesis $\mathbf{1 b}$. The more networks with the government a company has, the better its technological innovation performance will be.

Hypothesis 1c. The more networks with universities a company has, the better its technological innovation performance will be.

Hypothesis 1d. The more networks with users a company has, the better its technological innovation performance will be.

\subsection{IP Management}

It has been argued that IP management can be classified into two types: the management of human capital and the management of internal structural capital [62]. It is defined human capital as the economically valuable stock of knowledge embedded in humans that can be accumulated through education and training [63]. Previous studies have defined human capital as the source of internal structural capital and, more specifically, as that knowledge, skill, attitude and creativeness that serve as important tools for generating organizational profit [63,64]. They have also claimed that human capital contributes to an environment of innovation in the new product development process.

Reward systems for inventors comprise another factor affecting company innovation in the form of internal structural capital. It is shown that a company's number of patents, as a measure of its innovation, depends on the company's monetary and non-monetary reward systems [50]. The way European inventors respond to monetary and personal social rewards has been examined [65].

Innovation performance also depends on the specialist team used to manage a company's intellectual property strategies and practices. Many leading Japanese companies have invested more resources in IP management and organization than European companies do; thus, their innovation patterns were distinct from those of European companies during the 1980s and early 1990s [66]. The study has presented survey results describing the relationship between innovation results and responsibility and the size of the IP staff team [47].

This study has reclassified the human capital management factors in company's IP management into subgroups, including the size of the IP management staff and the existence of internal IP training. Internal structural capital management is further classified into provision for an IP management team and the amount of the compensation for inventions. Therefore, this study proposes the following series of hypotheses to test the relationship between a company's IP management capability and its technological innovation:

Hypothesis 2. Companies with more IP management work more vigorously toward technological innovation.

Hypothesis 2a. Companies with specialized IP teams work more vigorously toward technological innovation.

Hypothesis $\mathbf{2 b}$. Companies with more IP management staff innovate more actively.

Hypothesis 2c. Companies with an internal IP management education program work more vigorously toward technological innovation.

Hypothesis 2d. Companies with compensation schemes for invention activities work more actively toward technological innovation. 


\subsection{Control Variables}

We attempted to control for the company's internal and external characteristics comprising size of a company and age of a company, R\&D investment ratio, market structure and industry dummy since the previous studies suggested that those variables can give impact on the innovation performance inconsistently.

The size of a company does not significantly influence its technological innovation but that rather the characteristics of its intangible asset play a more important role in its innovative process $[2,67,68]$. However, studies conducted in this century show results different from those described above. It is argued that the bigger the company, the more intense is its use and implementation of knowledge obtained from universities $[69,70]$. The study shows that a company's size, measured by revenue, greatly influences its scale of open innovation [5].

Hypothesis 3. The bigger the company, the more active its technological innovation performance will be.

Much research has been done on the relationship between company age and innovation activity [71-73]. The company's age and product innovation activity may have an inversely proportional relationship because younger companies may pursue profits through product innovation rather than through process innovation and are thus more likely to initiate product innovation [72]. Meanwhile, it is revealed that there is a close relationship in the semiconductor and bio-engineering industries between a company's age and its rate of innovation [74].

Hypothesis 4. The younger a company is, the more technological innovation it will pursue; the older a company is, the more process innovation it will pursue.

Much international research has been conducted on the influence R\&D investment in intangible assets has on company value and performance [75-77]. These studies have revealed the cost-benefit relationship of R\&D using multiple regressions. Many more studies have indicated a significant relationship between $R \& D$ investment and technological innovation [2,78-81]. It is thus safe to assume that R\&D investment has a positive influence on a company's technological innovation activity. Meanwhile, it is analyzed the relationship between a company's R\&D concentration ratio and new product innovation, using R\&D concentration ratio as a proxy of a company's absorptive capability [82]. The study indicates that the R\&D concentration ratio shows an inverted U-shape relationship with new product innovation, thus suggesting that large-scale $R \& D$ funding is unnecessary for new product development.

Hypothesis 5. The more a company invests in RED, the more technological innovation activity it will have.

Most studies that predict the relationship between a company's monopolistic strength and its innovation activity use the HHI as a measure of the company and the market system [11,83-85]. The studies show that a higher CR3 led to a reduced R\&D concentration ratio $[40,86]$.

Hypothesis 6. The more monopolistic the market is, the more technological innovation activity will occur.

\section{Methodology}

\subsection{Empirical Model}

In this study, we employed two regression models: logistic and negative binomial regression. The logistic regression model was used to analyze tangible technological innovation performances: new product innovation and product improvement innovation. 
- Model I.

$$
\operatorname{Prob}(I N N O V=1)=1 /\left[1+e^{-\left(\alpha+\beta_{i} X_{i}\right)}\right]
$$

We employed both Prob( ) indicates the probability of technological innovation activity where INNOV, a dependent variable, has a value of 0 or $1 . X_{i}$, independent variables, consists of both qualitative and successive variable [11,87].

In this study, we also applied the following empirical model to analyze factors that affect intangible technological innovation: patent.

- $\quad$ Model II.

$$
\begin{aligned}
& \text { INNOV } V_{i}=\exp \left(\mathrm{a}_{1} \times \text { AGE }+\mathrm{a}_{2} \times \text { SIZE }+\mathrm{a}_{3} \times \mathrm{R} \& \mathrm{D}+\mathrm{a}_{4} \times \mathrm{HHI}\right. \\
& +\mathrm{a}_{6} \times \text { IP_DUTY }+\mathrm{a}_{7} \times \text { IP_EXPERT }+\mathrm{a}_{8} \times \text { IP_EDU }+\mathrm{a}_{9} \times \text { IP_RULE } \\
& +\mathrm{a}_{10} \times \text { TOTALNET }+\mathrm{a}_{11} \times \text { FIRMNET }+\mathrm{a}_{12} \times \mathrm{GOVNET} \\
& \left.+\mathrm{a}_{13} \times \text { UNINET }+\mathrm{a}_{14} \times \text { USERNET }+\mathrm{a}_{15} \times \text { IND }+\mathrm{u}_{i}\right)
\end{aligned}
$$

where $\mathrm{u}_{i}$ is the error term.

\subsection{Data}

We received 320 responses to our survey out of the 1580 new ICT companies registered with Korea Association of Smart Home, Korea Cable Television and Telecommunications Association, Korea Digital Cable Forum, Korea Creative Content Agency, Korea Digital Media Industry Association, Korea Association of Game Industry, Next generation Convergence Contents Industry Association, Korea Internet company Association, Korea Mobile Yearbook, Korea Mobile Industry Association, National IT Industry Promotion Agency and Korea Software Industry Association between September 2014 and November 2016. We analyzed 300 companies ( 82 hardware, 68 network, 78 software and 72 content companies). The total number of companies analyzed according to the ICT industry classifications is shown in Table 1. The questionnaire, based on the Oslo Manual [85], consisted of two parts: the company's current situation and its innovation activity.

Table 1. Number of respondents by industry.

\begin{tabular}{cccc}
\hline Industry Dummy Number & Classification & \# of Respondents & Component Ratio (\%) \\
\hline 1 & Hardware & 82 & 27.3 \\
2 & Network & 68 & 22.7 \\
3 & Software & 78 & 26.0 \\
4 & Content & 72 & 24.0 \\
\hline & & 300 & 100.0 \\
\hline
\end{tabular}

\subsection{Variables}

For its dependent variables, this study divided innovation outcomes into 'tangible' and 'intangible,' the former referring to new and improved products (as outlined in the Oslo Manual) and the latter to patents $[11,70,88]$, the most representative form of intellectual property. We used average number of new and improved products reported by survey respondents per year from January 2014 to December 2016. We also used average number of domestic and international patents granted by Korea Intellectual Patent Office, United States Patent and Trademark Office, European Patent Office, Japan Patent Office and World Intellectual Property Organization per year for the same period.

We used 15 variables as explanatory variables, as shown in Table 2. With respect to the age of company, we arrived at the actual age of the company as a variable by the subtraction of the year it was set up $[68,73,85]$. For size of company, we derived through an equation (R\&D expense/total company expense) based on average figures $[5,11]$. 
Many studies that analyzed the relationship between a company's monopolistic environment and its innovation performance used the Herfindahl-Hirschman Index (HHI) [76,84,85]. We assume that a company with a higher monopolistic environment will have greater innovation performance. We also include industry dummy variables of sub-sectors to look at the different characteristics on each innovation performances [2].

Each subordinate IP management capability variable has a binary value ( 0 or 1$)$ depending on whether each component (IP team, IP expert, IP training system and IP reward system) exists. The superordinate variable TOTAL_IP represents the number of IP management components from 0 to 4. The subordinate Cooperation Network variables also have a binary value ( 0 or 1$)$ depending on whether a company has each external cooperation partner (government, university, company and user group). TOTALNET represents the number of cooperation partners, from 0 to 4 .

Table 2 presents the category, criteria and related studies of each variable.

Table 2. Summary of variables.

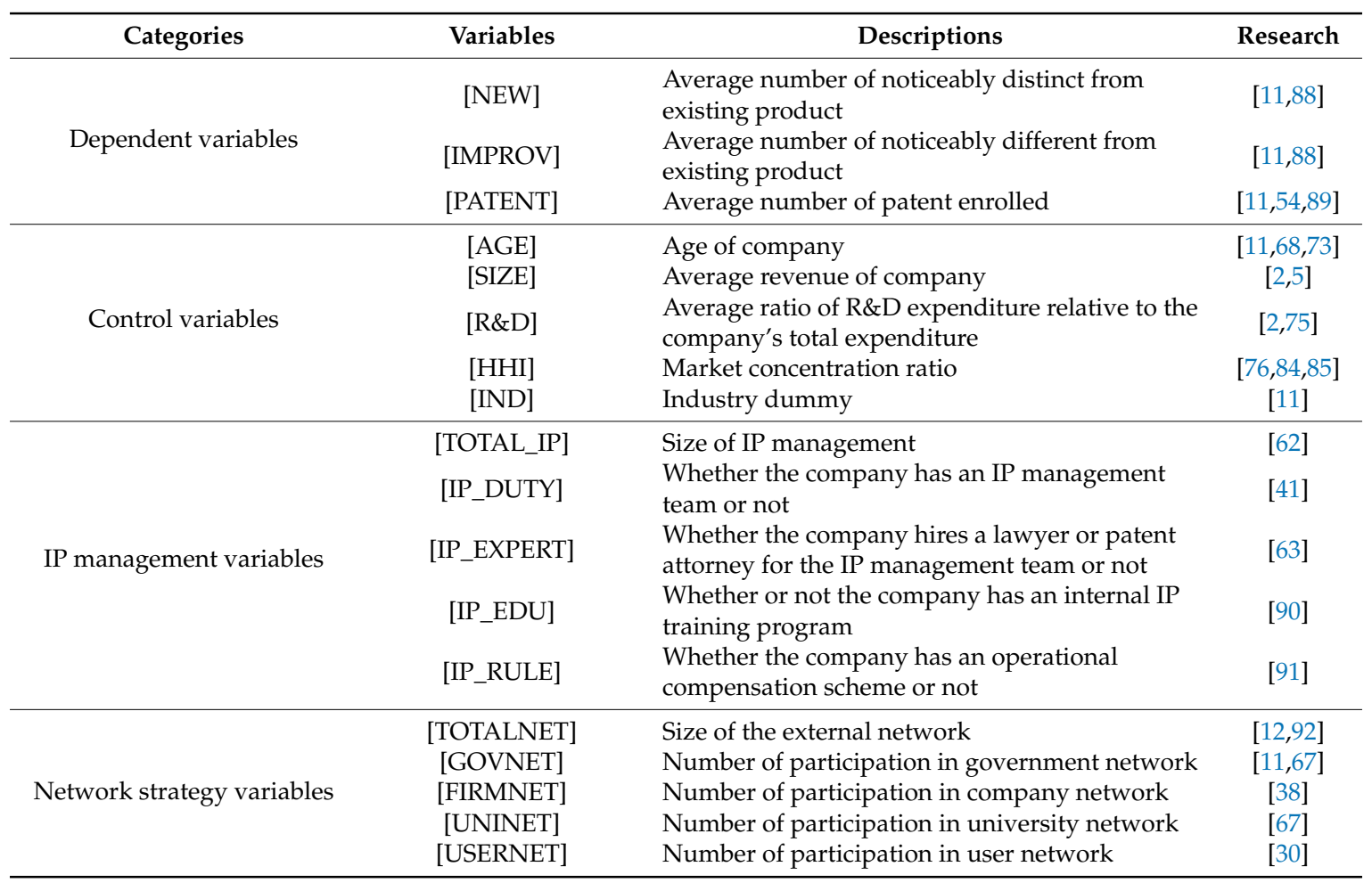

Table 3 presents the statistics and correlations of the variables. The Pearson correlation result shows that coefficients of the variables are low and the VIF test result are lower than 2. The VIF test results of each variable are lower than 3 , as shown in Table 3. These results indicate that all the explanatory variables could be included in the equation. 
Table 3. Statistical characteristics of independent variables.

\begin{tabular}{|c|c|c|c|c|c|c|c|c|c|c|c|c|c|c|c|c|c|}
\hline & Mean & Std. Dev. & VIF & 1 & 2 & 3 & 4 & 5 & 6 & 7 & 8 & 9 & 10 & 11 & 12 & 13 & 14 \\
\hline 1. AGE & 13.27 & 7.13 & 1.51 & 1.00 & & & & & & & & & & & & & \\
\hline 2. SIZE & 3.88 & 0.97 & 1.89 & 0.532 & 1.00 & & & & & & & & & & & & \\
\hline 3. R\&D & 3.44 & 0.85 & 1.32 & 0.157 & 0.475 & 1.00 & & & & & & & & & & & \\
\hline 4. HHI & 0.3665 & 0.2375 & 1.45 & -0.0940 & 0.4150 & -0.0120 & 1.0000 & & & & & & & & & & \\
\hline 5. TOTAL_IP & 1.86 & 0.98 & 2.03 & 0.035 & 0.354 & 0.375 & 0.051 & 1.0000 & & & & & & & & & \\
\hline 6. IP_DUTY & 0.68 & 0.4501 & 1.58 & -0.2399 & 0.4231 & 0.1258 & 0.3885 & 0.695 & 1.0000 & & & & & & & & \\
\hline 7. IP_RECOG & 0.85 & 0.7152 & 1.77 & -0.1223 & 0.3821 & 0.3521 & 0.1322 & 0.624 & 0.3902 & 1.0000 & & & & & & & \\
\hline 8. IP_EDU & 0.62 & 0.4926 & 1.99 & -0.2355 & 0.4887 & 0.2675 & 0.1221 & 0.587 & 0.2588 & 0.3622 & 1.0000 & & & & & & \\
\hline 9. IP_RULE & 0.68 & 0.4665 & 1.52 & -0.0537 & 0.3579 & 0.1325 & 0.1507 & 0.592 & 0.2933 & 0.3058 & 0.5291 & 1.0000 & & & & & \\
\hline 10. TOTALNET & 1.44 & 1.08 & 2.34 & 0.042 & 0.225 & 0.153 & -0.078 & 0.524 & 0.621 & 0.588 & 0.521 & 0.448 & 1.00 & & & & \\
\hline 11. FIRMNET & 0.78 & 0.42 & 1.92 & -0.072 & -0.016 & 0.099 & -0.123 & 0.504 & 0.532 & 0.520 & 0.415 & 0.424 & 0.775 & 1.00 & & & \\
\hline 12. GOVNET & 0.52 & 0.46 & 2.12 & 0.178 & 0.151 & 0.187 & -0.034 & 0.492 & 0.520 & 0.331 & 0.446 & 0.524 & 0.778 & 0.511 & 1.00 & & \\
\hline 13. UNINET & 0.35 & 0.31 & 2.35 & -0.009 & 0.120 & 0.109 & -0.021 & 0.502 & 0.634 & 0.526 & 0.551 & 0.223 & 0.705 & 0.575 & 0.427 & 1.00 & \\
\hline 14. USERNET & 0.72 & 0.63 & 2.25 & 0.036 & 0.124 & 0.127 & -0.157 & 0.558 & 0.665 & 0.533 & 0.423 & 0.301 & 0.641 & 0.578 & 0.442 & 0.601 & 1.00 \\
\hline
\end{tabular}




\section{Results}

The analytical results are presented in Table 4.

\subsection{New Product Innovation}

When examining the dependent variable New Product Innovation, TOTALNET, TOTAL_IP and R\&D shows a positive effect on Technological Innovation performance, while SIZE, AGE and HHI were statistically insignificant, validating Hypotheses 1, 2 and 5 and invalidating Hypotheses 3, 4 and 6.

When network and IP management was further divided into four elements, we found that FIRMNET and USERNET in network variable and IP_EXP and IP_EDU had a proportional relationship with New Product Innovation, validating Hypotheses 2b, 2c, 1a and 1d while the other variables had no statistically meaningful relationship, invalidating Hypotheses $2 \mathrm{a}, 2 \mathrm{~d}, 1 \mathrm{~b}$ and $1 \mathrm{c}$.

Dealing with industry dummy, software and content industry had more positive effects on New Product Innovation than hardware industry, while network industry showed fewer effects on New Product Innovation than hardware industry.

Table 4. Results for simple descriptive statistics for new ICT industry.

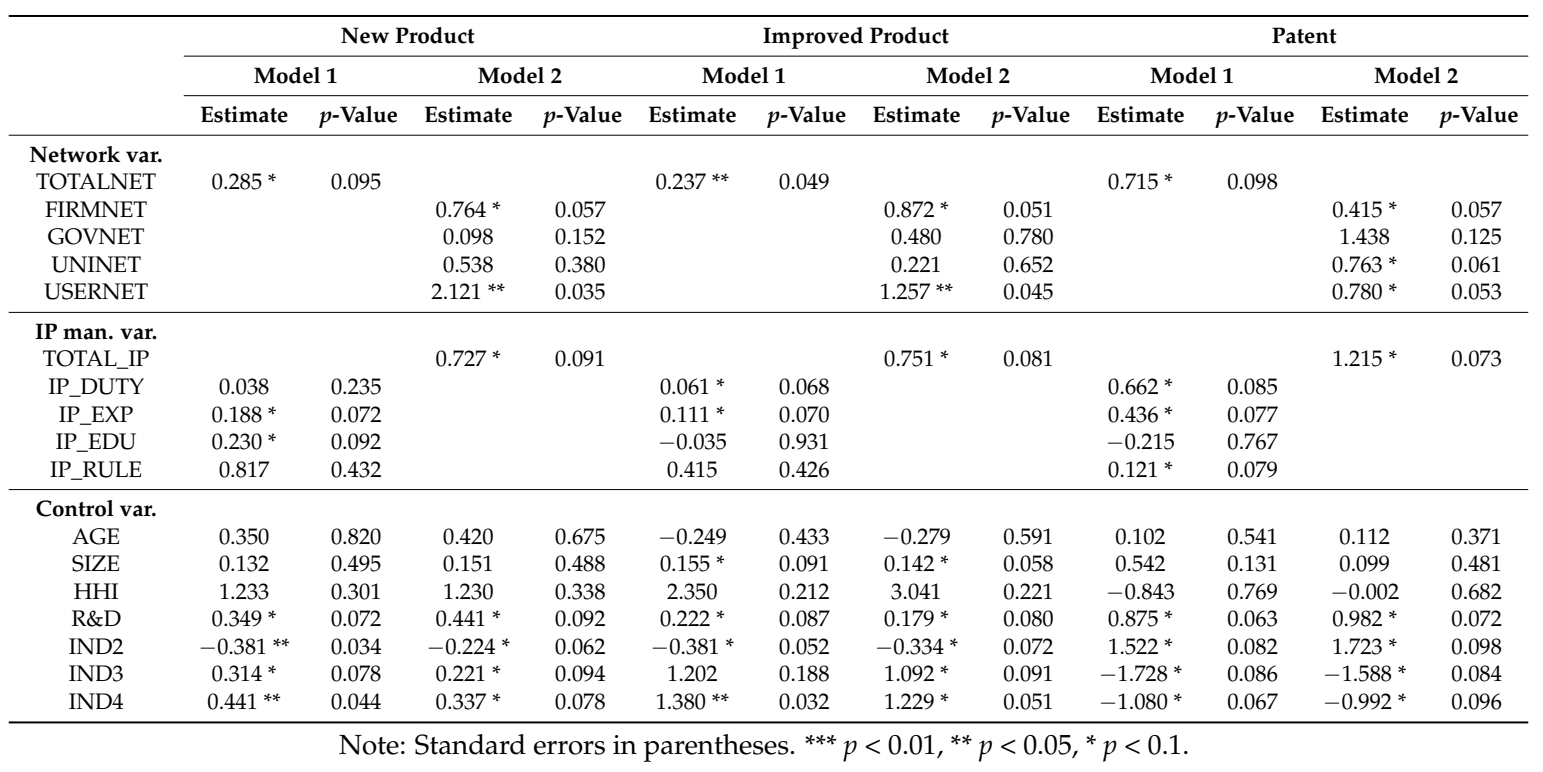

\subsection{Improved Product Innovation}

When improved product was considered as a dependent variable, TOTALNET, TOTAL_IP, SIZE and R\&D all had a positive influence on Technological Innovation Activity, validating Hypotheses 1, 2 and 5. Moreover, SIZE also was shown to have a statistically meaningful effect on Technological Innovation Activity, validating Hypothesis 3. The other variables, AGE and HHI, were shown to be independent from Technological Innovation Activity, invalidating Hypotheses 4 and 6.

When considering network and IP management, FIRMNET and USERNET in network variable and IP_DUTY and IP_EXP had a proportional effect on Improved Product while other variables were found not to have a meaningful relationship with Improved Product, validating Hypotheses 1a, 1b, 2a and $2 \mathrm{~d}$ but invalidating Hypotheses $1 \mathrm{c}, 1 \mathrm{~d}, 2 \mathrm{~b}$ and $2 \mathrm{c}$.

When looking at industry dummy, software industry had more positive effects on Improved Product Innovation than hardware industry, while network industry showed fewer effects on Improved Product Innovation than hardware industry. 


\subsection{Patents}

Concerning Patents, TOTALNET, TOTAL_IP and R\&D all formed proportional relationships validating Hypotheses 1,2 and 5. However, no statistically meaningful pattern could be found for the other elements, invalidating Hypotheses 3, 4 and 6.

Concerning network and IP management, all network and IP management variables except GOVNET and IP_EDU had a proportional effect on Technological Innovation Activity, validating Hypotheses 2a, 2b, 2d, 1a, 1c and 1d but invalidating Hypotheses $1 \mathrm{~b}$ and 2c.

Looking at industry dummy, network industry had more positive effects on patent than hardware industry, while software and content industry showed fewer effects on patent than network industry.

\section{Discussion and Conclusions}

The results of this study show that the intensity and variation of a company's technological cooperation have statistically meaningful impacts on its technological innovation. This study of the Korean new ICT industry has found that external networks, regardless of innovation type, have a positive effect on technological innovation, a finding consistent with $[11,12,59]$. However, while searching for the causes of technological innovation by dividing networks into four different types, many differences among network types were observed. This suggests that external cooperation is vital to new ICT companies' technological innovation and that companies in the Korean new ICT industry must expedite their technological innovation by cooperating with selected organizations, particularly considering specific programs. This study has contributed to the existing literature by focusing on the specific cooperative strategy of the company, from whom to acquire knowledge and ideas.

The results also indicate that IP management capability has a significant influence on technological innovation. Companies must thus construct technological innovation networks with various external sources and enhance their IP management capability in order to increase their technological innovation performance. The factors that influence technological innovation are elements of open innovation, indicating the open technological innovativeness of the new ICT industry. The results of this study can be reinterpreted in comparison with previous studies on the effect of human resource management on open innovation performance. The positive effects of specialized human resource are close to existing literature [93]. However, in the previous studies, the education on human resources showed various results $[94,95]$. This study has contributed to the existing literature by showing that training on human resources positively influences innovation of company in terms of IP management.

When companies want to apply the findings of this study in practice, they must consider the differences in network types. Networks with users, for example, were shown to have a positive effect on technological innovation in all cases. This, supported by the result of [30], reveals the importance of user involvement to company innovation in the smart age. Networks with other companies had a positive effect on technological innovation, revealing it to be an important factor in a company's innovative activities, along with user networks. Meanwhile, network with university was shown to have a positive effect only on intangible innovation performance in the new ICT industry, while network with government had no statistically meaningful effect on the industry in all cases. This is an inconsistent result with previous studies which suggested the positive role of university or government in company's innovation $[11,68,96]$.

Do these results mean that the cooperation with university or government does not give any impact on the innovation of new ICT companies in Korea? Instead, it is more worthwhile to take a close look at the types of cooperation with university or government in this case. The impact of cooperation with university or government on innovation can vary because of their diverse ways of cooperation [86,97]. For example, participating in a joint research project might give different impact on the company's innovation from acquiring a research fund, employing post-doctoral researcher [96] or benefitting from a regulatory support. It means that the current particular types of cooperation with university or government of Korean new ICT companies cannot give a significant positive effect 
on their innovation results except basic knowledge such as patent [1]. For further study, it will be interesting to find out what specific types of cooperation maximize the impact of cooperation with university or government.

When companies want to implement IP strategies, they must carefully choose IP management components. The results show that the level of IP management of a company has a significant positive effect on innovation generally, however the impact of specific actions for IP management varies by the specific type of innovation results. It may mean that a company needs to consider diverse sets of action plans in terms of IP management according to what type of innovation it pursuits. Specifically, the existence of IP-dedicated human resources has an important influence on company innovation. Additionally, whether the company has an IP management team or not had a statistically meaningful relationship with improved product innovation activity and intangible innovation performance. Internal IP education program had a statistically meaningful relationship only with the New Product Innovation category of tangible technological innovation. We may thus deduce that companies with internal IP-related education programs will have a higher chance of producing new product innovation. Finally, a compensation scheme for IP had a positive influence on the number of patent rather than any type of product innovation. In future research, it will be interesting to examine in detail the effect of strategic IP management [98] on the technological innovation of companies, such as supporting IP creation, responding to infringement and utilizing IP for strategic purposes.

Besides, SIZE was shown to be proportional only to Improved Product Innovation, indicating that bigger companies are more likely to produce product innovation than are smaller companies, supporting the result of the study by [11] on production companies. Market structure did not have a statistically meaningful impact on the new ICT industry and company age had no relationship with technological innovation activity, regardless of innovation type or sample size, making it difficult to validate the view of [73] that younger companies are more likely to pursue technological innovation.

This study has limitations, however, which should be addressed by future studies. First, we did not distinguish between the quantity and quality of technological innovation. For example, a company that has released products with supplemental value and one that has only released a single product were both considered to be innovative. Moreover, the concept 'new,' a central factor in innovation activity, is highly subjective and depends on the outlooks of the companies surveyed. Due to the limitations imposed by the sample size and independent variables, a more detailed analysis could not be made. The control or analysis of company characteristics such as CEOs' drive toward technological innovation, competition strategy and stages of growth may produce additional insights into the technological innovation of new ICT companies. Future studies should control all the variables relevant to technological innovation and employ a systemic conception and quantification of the technological innovation of new ICT companies.

Author Contributions: Conceptualization, E.K. and S.Y.K.; Methodology, E.K. and S.Y.K.; Data Curation, S.Y.K. and E.K.; Writing-Original Draft Preparation, E.K.; Writing-Review \& Editing, E.K. and S.Y.K.; Supervision, E.K.; Project Administration, E.K.; Funding Acquisition, S.Y.K.

Acknowledgments: This research is supported by The International Science and Business Belt Program through the Ministry of Science, ICT and Future Planning (2016K000282), Republic of Korea. This research was supported by a grant of the Medical Research Information Center of the National Research Foundation through the Ministry of Science and ICT (2018R1A6A6040880), Republic of Korea. This research was funded by Korea Institute of Science and Technology Information (K-18-L13-C02-S01), Republic of Korea.

Conflicts of Interest: The authors declare no conflict of interest.

\section{References}

1. Nieto, M.J.; Santamaría, L. The importance of diverse collaborative networks for the novelty of product innovation. Technovation 2007, 27, 367-377. [CrossRef] 
2. Kim, S.; Kim, H.; Kim, E. How knowledge flow affects Korean ICT manufacturing firm performance: A focus on open innovation strategy. Technol. Anal. Strateg. Manag. 2016, 28, 1167-1181. [CrossRef]

3. Yun, J.J.; Jeong, E.; Park, J. Network Analysis of Open Innovation. Sustainability 2016, 8, 729. [CrossRef]

4. Lee, Y.G.; Lee, J.H.; Song, Y.I.; Kim, H.J. Technological convergence and open innovation in the mobile telecommunication industry. Asian J. Technol. Innov. 2008, 16, 45-62. [CrossRef]

5. Lichtenthaler, U.; Ernst, H. Opening up the innovation process: The role of technology aggressiveness. RED Manag. 2009, 39, 38-54.

6. Tomlinson, P.R. Co-operative ties and innovation: Some new evidence for UK manufacturing. Res. Policy 2010, 39, 762-775. [CrossRef]

7. Yun, J.J.; Jeon, J.; Park, K.; Zhao, X. Benefits and Costs of Closed Innovation Strategy: Analysis of Samsung's Galaxy Note 7 Explosion and Withdrawal Scandal. J. Open Innov. 2018, 4, 20. [CrossRef]

8. Fransman, M. The New ICT Ecosystem; Cambridge University Press: Cambridge, UK, 2010.

9. Evans, D.S.; Hagju, A.; Schmalensee, R. Invisible Engines: How Software Platforms Drive Innovation and Transform Industries; MIT Press: Cambridge, MA, USA, 2009.

10. Ritala, P.; Ritala, P.; Agouridas, V.; Assimakopoulos, D.; Gies, O. Value creation and capture mechanisms in innovation ecosystems: A comparative case study. Int. J. Technol. Manag. 2013, 63, 244-267. [CrossRef]

11. Kim, E.; Lee, D.; Kim, J.H. How collaboration networks affect innovation in Korea's information and communication technology industry in the era of Internet of Things. Asian J. Technol. Innov. 2016, 24, $202-221$. [CrossRef]

12. Laursen, K.; Salter, A. Open for innovation: The role of open innovativeness in explaining innovation performance among U.K. manufacturing firms. Strateg. Manag. J. 2006, 27, 131-150. [CrossRef]

13. Greco, M.; Grimaldi, M.; Cricelli, L. Hitting the nail on the head: Exploring the relationship between public subsidies and open innovation efficiency. Technol. Forecast. Soc. Chang. 2017, 118, 213-225. [CrossRef]

14. Love, L.H.; Mansury, M.A. External linkages, R\&D, and innovation performance in US business services. Ind. Innov. 2007, 14, 477-496.

15. Yoon, C.; Lee, K.; Yoon, B.; Toulan, O. Typology and Success Factors of Collaboration for Sustainable Growth in the IT Service Industry. Sustainability 2017, 9, 2017. [CrossRef]

16. Veugelers, R. New ICT Sectors: Platforms for European Growth? Bruegel Policy Contribution: Bruxelles, Belgium, 2012; Volume 14.

17. Kim, E.; Lee, D.; Bae, K.; Rim, M. Developing and Evaluating a New ICT Innovation System: A Case of Korea's Smart Media Industry. ETRI J. 2015, 37, 1044-1054. [CrossRef]

18. Raasch, C.; Herstatt, C.; Lock, P. The dynamics of user innovation: Drivers and impediments of innovation activities. Int. J. Innov. Manag. 2008, 12, 377-398. [CrossRef]

19. Overby, E.; Bharadwaj, A.; Sambamurthy, V. Enterprise agility and the enabling role of information technology. Eur. J. Inf. Syst. 2016, 15, 120-131. [CrossRef]

20. Agarwal, R.; Gao, G.; DesRoches, C.; Jha, A.K. Research commentary-The digital transformation of healthcare: Current status and the road ahead. Inf. Syst. Res. 2010, 21, 796-809. [CrossRef]

21. Matt, C.; Hess, T.; Benlian, A. Digital transformation strategies. Bus. Inf. Syst. Eng. 2015, 57, 339-343. [CrossRef]

22. Lee, M.; Yun, J.J.; Pyka, A.; Won, D.; Kodama, F.; Schiuma, G.; Park, H.; Jeon, J.; Park, K.; Jung, K.; et al. How to Respond to the Fourth Industrial Revolution, or the Second Information Technology Revolution? Dynamic New Combinations between Technology, Market, and Society through Open Innovation. J. Open Innov. 2018, 4, 21. [CrossRef]

23. Wang, S.; Wan, J.; Li, D.; Zhang, C. Implementing smart factory of industrie 4.0: An outlook. Int. J. Distrib. Sens. Netw. 2016, 12, 3159805. [CrossRef]

24. Granstrand, O.; Bohlin, E.; Oskarsson, C.; Sjöberg, N. External technology acquisition in large multi-technology corporations. RED Manag. 1992, 22, 111-134.

25. Cappa, F.; Laut, J.; Nov, O.; Giustiniano, L.; Porfiri, M. Activating social strategies: Face-to-face interaction in technology-mediated citizen science. J. Environ. Manag. 2016, 182, 374-384. [CrossRef] [PubMed]

26. Zhang, J. Facilitating exploration alliances in multiple dimensions: The influences of firm technological knowledge breadth. RED Manag. 2016, 46, 159-173.

27. Natalicchio, A.; Petruzzelli, A.M.; Garavelli, A.C. A literature review on markets for ideas: Emerging characteristics and unanswered questions. Technovation 2014, 34, 65-76. [CrossRef] 
28. Cammarano, A.; Caputo, M.; Lamberti, E.; Michelino, F. Open innovation and intellectual property. A knowledge-based approach. Manag. Decis. 2017, 55, 1182-1208. [CrossRef]

29. Lichtenthaler, U. Open innovation: Past research, current debates, and future directions. Acad. Manag. Perspect. 2011, 25, 75-93.

30. Von Hippel, E. Comment on 'Is open innovation a field of study or a communication barrier to theory development'? Technovation 2010, 30, 555. [CrossRef]

31. Miorandi, D.; Sicari, S.; De Pellegrini, F.; Chlamtac, I. Internet of things: Vision, applications and research challenges. Ad Hoc Netw. 2012, 10, 1497-1516. [CrossRef]

32. Varian, H.R. Economics of Information Technology; University of California: Berkeley, CA, USA, 2003.

33. Schaffers, H.; Komninos, N.; Pallot, M.; Aguas, M.; Almirall, E.; Bakici, T.; Barroca, J.; Carter, D.; Corriou, M.; Fernadez, J.; et al. Smart Cities as Innovation Ecosystems Sustained by the Future Internet; FIREBALL White Paper 65; Brussels, Belgium, 2012. Available online: https:/ /hal.inria.fr/hal-00769635/document (accessed on 17 July 2018).

34. Cooper, R.G. The stage-gate idea-to-launch process-Update, what's new, and NexGen systems. J. Prod. Innov. Manag. 2008, 25, 213-232. [CrossRef]

35. Enkel, E.; Gassmann, O.; Chesbrough, H. Open R\&D and open innovation: Exploring the phenomenon. RED Manag. 2009, 39, 311-316.

36. Benkhelifa, E.; Abdel-Maguid, M.; Ewenike, S.; Heatley, D. The internet of things: The eco-system for sustainable growth. In Proceedings of the 2014 IEEE/ACS 11th International Conference on Computer Systems and Applications (AICCSA), Doha, Qatar, 10-13 November 2014; pp. 836-842.

37. Lee, N.; Nystén-Haarala, S.; Huhtilainen, L. Interfacing Intellectual Property Rights and Open Innovation; Department of Industrial Management Research Report 225; Lappeenranta University of Technology: Lappeenranta, Finland, 2010.

38. Chesbrough, H. The era of open innovation. MIT Sloan Manag. Rev. 2003, 44, 35-41.

39. Arranz, N.; Arroyabe, J.C.F. The choice of partners in R\&D cooperation: An empirical analysis of Spanish firms. Technovation 2008, 28, 88-110.

40. Lee, B.; Cho, H.H.; Shin, J. The relationship between inbound open innovation patents and financial performance: Evidence from global information technology companies. Asian J. Technol. Innov. 2015, 23, 289-303. [CrossRef]

41. Hong, A.; Bhattacharyya, D.; Geis, G.T. The role of M\&A in market convergence: Amazon, Apple, Google and Microsoft. Glob. Econ. Financ. J. 2013, 6, 53-73.

42. West, J. Does Appropriability Enable or Retard Open Innovation? Open Innovation: Researching a New Paradigm; Chesbrough, H.W., Vanhaverbeke, W., West, J., Eds.; Oxford University Press: Oxford, UK, 2006; pp. 109-133.

43. Gallini, N.T. The economics of patents: Lessons from recent U.S. patent reform. J. Econ. Perspect. 2002, 16, 131-154. [CrossRef]

44. Hagedoorn, J.; Ridder, A.K. Open innovation, contracts, and intellectual property rights: An exploratory empirical study. In Proceedings of the Open Innovation: New Insights and Evidence Conference, London, UK, 25-26 June 2012.

45. Yun, J.J.; Won, D.; Park, K. Dynamics from open innovation to evolutionary change. J. Open Innov. 2016,2 , 7. [CrossRef]

46. Yun, J.J. How do we conquer the growth limits of capitalism? Schumpeterian Dynamics of Open Innovation. J. Open Innov. 2015, 1, 17. [CrossRef]

47. Hagedoorn, J.; Zobel, A.K. The role of contracts and intellectual property rights in open innovation. Technol. Anal. Strateg. Manag. 2015, 27, 1050-1067. [CrossRef]

48. Peeters, C.; van Pottelsberghe de la Potterie, B. Innovation strategy and the patenting behavior of firms. J. Evolut. Econ. 2006, 16, 109-135. [CrossRef]

49. Pitkethly, R.H. Intellectual property strategy in Japanese and UK companies: Patent licensing decisions and learning opportunities. Res. Policy 2001, 30, 425-442. [CrossRef]

50. Honig-Haftel, S.; Martin, L. The effectiveness of reward systems on innovative output: An empirical analysis. New ICT Bus. Econ. 1993, 5, 261-269. [CrossRef]

51. Suh, D.; Oh, D.; Kim, J. Do IP management strategies spur innovative outputs and firm's performance? Evidence from Korean manufacturing industries. In Proceedings of the PICMET'12: Technology Management for Emerging Technologies, Vancouver, BC, Canada, 29 July-2 August 2012. 
52. Teece, D.J.; Pisano, G.; Shuen, A. Dynamic capabilities and strategic management. Strateg. Manag. J. 1997, 18, 509-533. [CrossRef]

53. Wang, C.L.; Ahmed, P.K. Dynamic capabilities: A review and research agenda. Int. J. Manag. Rev. 2007, 9, 31-51. [CrossRef]

54. Barney, J. Firm resources and sustained competitive advantage. J. Manag. 1991, 17, 99-120. [CrossRef]

55. Verona, G. A resource-based view of product development. Acad. Manag. Rev. 1999, 24, 132-142. [CrossRef]

56. Galende, J.; de la Fuente, J.M. Internal factors determining a firm's innovative behavior. Res. Policy 2003, 32, 715-736. [CrossRef]

57. Hwang, J.E.; Kim, E.; Kim, S. Factors affecting open technological innovation in open source software companies in Korea. Innov. Manag. Policy Pract. 2009, 11, 279-290. [CrossRef]

58. Feldman, M.P. Knowledge complementarity and innovation. Small Bus. Econ. 1994, 6, 363-372. [CrossRef]

59. Love, J.; Roper, S. The determinants of innovation: R\&D technology transfer and networking effects. Rev. Ind. Organ. 1999, 15, 43-64.

60. Kim, S.H. Building the Innovation Network Strategy for the Open Technology Innovation by Major Industry; Policy Report in Science and Technology Policy Institute (STEPI): Washington, DC, USA, 2007; Volume 19.

61. Faems, D.; Van Looy, B.; Debackere, K. Interorganizational collaboration and innovation: Toward a portfolio approach. J. Prod. Innov. Manag. 2005, 22, 238-250. [CrossRef]

62. Bontis, N. Intellectual capital: An exploratory study that develops measures and models. Manag. Decis. 1988, 36, 63-76. [CrossRef]

63. Nelson, R.; Winter, S. An Evolutionary Theory of Economic Change; Belknap Press: Cambridge, MA, USA, 1982.

64. Chen, H.M.; Lin, K.J. The role of human capital cost in accounting. J. Intellect. Cap. 2004, 5, 116-130. [CrossRef]

65. Giuri, P.; Mariani, M.; Brusoni, S.; Crespi, G.; Francoz, D.; Gambardella, G.W.; Geuna, A.; Gonzales, R.; Harhoff, D.; Hoisl, K.; et al. Inventors and invention processes in Europe: Results from the PatVal-EU survey. Res. Policy 2007, 36, 1107-1127. [CrossRef]

66. Granstrand, O. The Economics and Management of Intellectual Property-Towards Intellectual Capitalism; Edward Elgar Publishing Ltd.: London, UK, 1999.

67. Pavitt, K.; Robinson, M.; Townsend, J. The size distribution of innovation firms in UK: 1945-1983. J. Ind. Econ. 1987, 35, 297-316. [CrossRef]

68. Cohen, W.M.; Levin, R.C.; Mowery, D.C. Firm size and R\&D intensity: A re-examination? J. Ind. Econ. 1987, 35, 543-563.

69. Cohen, W.M.; Nelson, R.R.; Walsh, J. Link and impacts: The influence of public research on industrial R\&D. Manag. Sci. 2002, 48, 1-23.

70. Mohnen, P.; Hoareau, C. What type of enterprise forges close links with universities and government labs evidence from CIS2. Manag. Decis. Econ. 2003, 24, 133-146. [CrossRef]

71. Gort, M.; Klepper, S. Time paths in the diffusion of product innovations. Econ. J. 1982, 92, 630-653. [CrossRef]

72. Klepper, S.; Graddy, E. The evolution of new industries and the determinants of market structure. RAND J. Econ. 1990, 21, 24-44. [CrossRef]

73. Klepper, S. Entry, exit, growth, and innovation over the product life cycle. Am. Econ. Rev. 1996, 86, 562-583.

74. Sorensen, J.B.; Stuart, T.E. Aging obsolescence, and organizational innovation. Adm. Sci. Q. 2000, 45, 81-112. [CrossRef]

75. Brown, M.G.; Svenson, R.A. RTM classic: Measuring R\&D productivity. Res. Technol. Manag. 1998, 41, $30-35$.

76. Han, B.H.; Manry, D. The valid-relevance of R\&D and advertising expenditure: Evidence from Korea. Int. J. Account. 2004, 39, 101-128.

77. Jeffrey, L.C.; Morel, M. The valuation relevance of R\&D expenditure: Time series evidence. Int. Rev. Financ. Anal. 2005, 14, 304-325.

78. Acs, Z.J.; Audretsch, D.B. Innovation in large and small firms: An empirical analysis. Am. Econ. Rev. 1988, 78, 678-690. [CrossRef]

79. Kleinknecht, A.; Reijnen, J.O.N. Why do firms co-operate on R\&D: An empirical study. Res. Policy 1992, 21, 347-360.

80. Kondo, M. R\&D dynamics of creating patents in the Japanese industry. Res. Policy 1999, 28, 587-600.

81. Shefer, D.; Frenkel, A. Firm Size and Innovation: An Empirical Analysis. Technovation 2005, 25, 25-32. [CrossRef] 
82. Stock, N. Absorptive capacity and new product development. J. High Technol. Manag. Res. 2001, 12, 77-91. [CrossRef]

83. Scott, J.T. Firm versus Industry Variability in RED Intensity. RED, Patents, and Productivity; Griliches, Z., Ed.; University of Chicago Press: Chicago, IL, USA, 1984; pp. 233-245.

84. Levin, R.C.; Cohen, W.M.; Mowery, D.C. R\&D appropriability opportunity, market structure: New evidence on some schumpeterian hypothesis. Am. Econ. Rev. 1985, 75, 20-24.

85. Jung, H.; Kim, E.; Kim, S.; Hwang, J. How diversification affects innovation by a Korean mobile content firm. Int. J. Mob. Commun. 2012, 10, 512-535. [CrossRef]

86. Lee, K.R. University-Industry R\&D Collaboration in Korea's National Innovation System. Sci. Technol. Soc. 2014, 19, 1-25.

87. Affifi, A.A.; Clark, V. Computer-Aided Multivariate Analysis; Van Nostrand-Reinhold: New York, NY, USA, 1990.

88. Organization for Economic Co-Operation and Development (OECD). Proposed Guidelines for Collecting and Interpreting Technological Innovation Data: The 'Oslo Manual'; OECD: Paris, France, 1996.

89. Griliches, Z. Patent statistics as economic indicators: A survey. J. Econ. Lit. 1990, 28, 1661-1707.

90. Lucas, R.E. On the mechanics of economic development. J. Monet. Econ. 1988, 22, 3-42. [CrossRef]

91. Nelson, R.R.; Phelps, E.S. Investment in Humans, Technological Diffusion, and Economic Growth. Am. Econ. Rev. 1966, 56, 69-75.

92. Audretsch, D.B.; Vivarelli, M. Small Firms and RED Spillovers: Evidence from Italy; CEPR Discussion Paper; CEPR: Washington, DC, USA, 1994; Volume 927.

93. Jiang, K.; Lepak, D.P.; Hu, J.; Baer, J.C. How does human resource management influence organizational outcomes? A meta-analytic investigation of mediating mechanisms. Acad. Manag. J. 2012, 55, 1264-1294. [CrossRef]

94. Vega-Jurado, J.; Gutiérrez-Gracia, A.; Fernández-de-Lucio, I. Does external knowledge sourcing matter for innovation? Evidence from the Spanish manufacturing industry. Ind. Corp. Chang. 2009, 18, 637-670. [CrossRef]

95. Natalicchio, A.; Messeni Petruzzelli, A.; Cardinali, S.; Savino, T. Open innovation and the human resource dimension: An investigation into the Italian manufacturing sector. Manag. Decis. 2018, 56, 1271-1284. [CrossRef]

96. Schartinger, D.; Rammer, C.; Fischer, M.M.; Fröhlich, J. Knowledge interactions between universities and industry in Austria: Sectoral patterns and determinants. Res. Policy 2002, 31, 303-328. [CrossRef]

97. Kitagawa, F. Universities-Industry Links and Regional Development in Japan Connecting Excellence and Relevance? Sci. Technol. Soc. 2009, 14,1-33. [CrossRef]

98. Reitzig, M. Strategic management of intellectual property. MIT Sloan Manag. Rev. 2004, 45, 35-40. 